\title{
STRATEGIES FOR DETERMINING GERMAN NOUNS' GENDER BY COLLEGE STUDENTS
}

\author{
Svitlana Kiyko \\ https://orcid.org/0000-0003-4964-7043 \\ Scopus Author ID: $\underline{36613751900}$ \\ s.kiyko@,chnu.edu.ua \\ Yuriy Fedkovych Chernivtsi National University, Ukraine \\ Yuriy Kiyko \\ https://orcid.org/0000-0002-2251-2811 \\ Scopus Author ID: $\underline{36613088300}$ \\ y.kiyko@chnu.edu.ua \\ Yuriy Fedkovych Chernivtsi National University, Ukraine \\ Viktor Drebet \\ https://orcid.org/0000-0003-2824-793X \\ Scopus Author ID: $\underline{36612754000}$ \\ vdrebet@ukr.net \\ Ternopil Volodymyr Hnatiuk National Pedagogical University, Ukraine
}

Received August 4, 2020; Revised September 5, 2020; Accepted October 12, 2020

\begin{abstract}
The article is dedicated to the study of strategies for determining the gender of nouns of the German language by Ukrainian-speaking first-year-students at the Yuriy Fedkovych Chernivtsi National University, Ukraine. The purpose of the study is to establish the strategies for determining the gender of nouns on the basis of phonetic, morphological, and semantic criteria and experimentally trace the impact of interlingual and intralingual interference in the process of gender categorization of nouns. The material of the study included 60 nouns, out of which 30 were phonetic equivalents and 30 - semantic ones. Each group contained 10 nouns of the masculine, feminine, and neuter gender respectively, with the same number of structurally different nouns among them, which were selected according to semantic, morphological, and phonetic rules of gender identification. To identify strategies for determining the gender of German nouns, two psycholinguistic experiments were held with a month interval. The experiments involved 30 first-year-students at the University of Chernivtsi (German department), who had to decide whether the noun gender specified in DMDX program is correct. Thus, the article in half of the given nouns was set incorrectly in the program. The obtained results indicate that the gender of the noun of the native language significantly affects gender determining of the German phonetic equivalent ( $85 \%$ of all mistakes in determining the gender in Experiment 1 and
\end{abstract}

(C) Kiyko, Svitlana; Kiyko, Yuriy, Drebet, Viktor, 2020.

This is an Open Access article distributed under the terms and conditions of the Creative Commons Attribution 4.0 International Licence (http://creativecommons.org/ licenses/by/4.0).

East European Journal of Psycholinguistics, 7(2),107-119. https://doi.org/10.29038/eejpl.2020.7.2.kiy 
$47 \%$ - in Experiment 2). The students also focus on the suffixes or endings of German nouns when choosing the correct gender. Phonetic or semantic rules for determining gender play a secondary role. The gender of a noun in the native language prevents the correct choice of the gender in the German language, which is twice as often recorded for phonetic equivalents.

Keywords: gender of noun, strategies for determining gender, interference, phonetic, morphological, and semantic principles, the German language.

Кійко Світлана, Кійко Юрій, Дребет Віктор. Стратегії визначення роду німецьких іменників університетськими студентами.

Анотація. Статтю присвячено стратегіям визначення роду іменників німецької мови україномовними студентами першого курсу Чернівецького національного університету імені Юрія Федьковича. Мета дослідження - встановити стратегії визначення роду на основі фонетичних, морфологічних та семантичних критеріїв i екпериментально прослідкувати вплив міжмовної і внутрішньомовної інтерференції в процесі категоризації іменників за родом. Матеріалом дослідження слугували 60 іменників, 3 них 30 фонетичних i 30 семантичних відповідників. Кожна група містила по 10 іменників чоловічого, жіночого і середнього родів, серед яких - однакова кількість структурно різнотипних іменників, відібраних відповідно до семантичних, морфологічних і фонетичних правил визначення роду. Для встановлення стратегій визначення роду німецьких іменників здійснено два психолінгвістичні експерименти 3 одномісячним інтервалом. В експериментах взяли участь 30 студентів, які мали вирішити, чи вказаний у програмі DMDX рід іменника правильний. При цьому у половині запропонованих іменників артикль був заданий у програмі некоректно. Отримані результати свідчать про те, що рід іменника рідної мови істотно впливає на визначення роду німецького фонетичного відповідника (85\% усіх помилок на визначення роду в Експерименті 1 і $47 \%$ в Експерименті 2). Студенти орієнтуються при виборі правильного роду також на суфікси або закінчення німецьких іменників. Фонетичні або семантичні правила визначення роду відіграють другорядну роль. Рід іменника в рідній мові перешкоджає правильному вибору роду в німецькій мові, що вдвічі частіше зафіксовано для фонетичних еквівалентів.

Ключові слова: рід іменника, стратегії визначення роду, інтерференція, фонетичні, морфологічні та семантичні принциии, німецька мова.

\section{Introduction}

The grammatical category of gender, called by Köpcke (1982, p. 4-5) one of the least logical and most unpredictable categories, is a characteristic feature of the grammatical structure of almost all Indo-European languages. Problems of a gender category are closely related to many important aspects of the methodology of learning foreign languages, the interaction of different language levels and the relationship between lexical and grammatical meanings of the word, and therefore are the focus of modern research.

It is widely believed that the study of the gender of German nouns creates significant problems for students and even a high level of German language skills does not guarantee the absence of mistakes in choosing the gender or agreement of adjectives with nouns (Bordag, 2006, p.103; Menzel, 2004, p. 55). In a survey of German language teachers conducted by Sperber (1989, p. 148), mistakes in determining gender are considered one of the most important sources of mistakes in teaching German, as the gender of nouns is an arbitrary category. Although a number of phonetic, morphological and semantic rules for determining the gender 
of nouns is put forward in many German grammars. Helbig and Buscha (2001, p. 245) note that it is impossible to "establish easy-to-use rules for determining gender" for the vast majority of nouns. It is true that a lot of nouns in the German language may end the same, but belong to different genders, such as: der Mantel (masculine) - die Fabel (feminine) - das Mittel (neuter), der Junge (masculine) die Rose (feminine) - das Auge (neuter). Despite the coincidence of natural and grammatical genders such as der Mann (masculine) - die Frau (feminine) - das Kind (neuter), der Bulle (masculine) - die Kuh (feminine) - das Kalb (neuter), cases of their differences are possible as well, such as: das Weib (neuter), etc. Most grammar guides recommend memorizing a noun at once with the appropriate article, which makes the study of gender in German a difficult and time-consuming process. This means that gender in German belongs to those grammatical categories that complicate the process of language learning, slow down the reproductive characteristics of speech and serve as an indicator for native speakers to recognize foreigners.

Several domestic and foreign authors (Doleschal, 2004; Kiyko, 2017; Köpcke, 1982) tried to formulate unambiguous phonetic, morphological, and semantic rules for determining the gender of nouns. Phonetic rules are based on the number of syllables and characteristics of sounds. Thus, one-syllable nouns ending in $/ \mathrm{t} /$ with the previous non-syllabic fricative belong to the feminine gender: die Schlucht, die Luft, die Fracht (Doleschal, 2004, p. 4). One-syllable nouns beginning with $\mathrm{kn}$ - or $d / t+r$ - are usually of masculine gender: der Knopf, der Draht. The more consonants at the beginning or end of a word, the more often the noun belongs to masculine gender: der Strumpf (Köpcke, 1982, p. 88). However, there are numerous exceptions to these rules, in particular, only $63.6 \%$ of one-syllable nouns ending in $/ \mathrm{t} /$ with the previous non-syllabic fricative (35 nouns out of 55 analyzed) are feminine: die Fahrt, die Schlacht, die Kunst, but: der Durst, der Frost, etc. Among one-syllable masculine nouns beginning with $\mathrm{kn}$-, there is one exception - das Knie, but the number of nouns under this rule is only 15 . Two- and multi-syllable nouns ending in schwa mainly belong to the feminine gender (die Flasche, die Scheibe), but there are numerous exceptions to the masculine and neuter genders (der Hase, das Auge). In this regard, Bewer (2003, p. 90) notes that phonetic rules help not to identify the gender of a noun, but rather to exclude one of the genders, so nouns are still difficult to divide between the other two genders, often between masculine and neuter.

Morphological rules refer to the derivational affixes of nouns. Spitz (1965, pp. 35-43), based on ten academic grammars of the German language, identified 127 formal rules for determining the gender. According to these rules German nouns with suffixes -s, -er, -ig, -(l)ing, borrowings ending in -ant, -är, -ent, -et, -eur, -ist, -löge, -iker, -ismus, -or, -us, -tum and non-suffixal deverbals belong to masculine gender. Nouns of the feminine gender have suffixes -in, -ei, -heit, -keit, -schaft, -ung, also borrowings ending in -age, -ät, -anz, -enz, -ie, -ik, -ion, -ur belong to this group. Nominalised words are of neuter gender, nouns with suffixes -chen, -lein, -icht, -tum, borrowings in -ett, -in, -il, - $(g) m a,-o$, -ment, -um, collective nouns with 
prefix Ge- and most often nouns with suffix -nis. However, nouns in -el may be either of masculine (der Löffel, der Apfel) or feminine (die Gabel, die Tafel) or neuter (das Mittel, das Rätsel) gender. Doleschal (2004, p. 3) highlights in this regard that purely a formal classification system that can cover all nouns does not exist, so it is necessary to use the semantic categories for determining gender of nouns.

According to semantic criteria, there are groups of nouns that correlate with the one of three genders. Thus, the names of the cardinal directions, celestial bodies, precipitation and winds, minerals, seasons, months, days of the week, alcoholic beverages, coffee and tea varieties, cars, currency issues, etc. belong to masculine gender. Nouns of feminine gender denote tree names, fruit, flowers, numbers, scientific disciplines, ships, aircraft, cigarette brands. Neuter gender covers nouns denoting physical mass, chemical elements and metals, colors, languages, letters, games, cities, islands and continents, cafes and restaurants, beer varieties, hotels, cinemas, medication, ditergents (Köpcke, 1982, p. 71; Menzel, 2004, pp. 63-64). However, such reference of the gender of a noun to its semantics is applicable only to some lexical groups. Nouns with a high frequency of usage, as a rule, are not grouped semantically according to gender, for example: names of the parts of face (der Mund, die Nase, das Ohr), cutlery (der Löffel, die Gabel, das Messer), tools (der Nagel, die Schraube, das Brett).

In the analysis of the category of gender, a question that arises constantly is which criteria students use to refer a particular noun to one of the three genders. Thus, the goal of our research is to establish the principles of assigning gender to German nouns by students, whose native language is Ukrainian. Here it is important to identify the relation between phonetic, morphological or semantic features of a noun and its gender.

Various studies on gender of German nouns (Hunt 2018; Onysko et al. 2013; Schwichtenberg and Schiller 2004; Steinmetz 1986; 2006; Zubin and Köpcke 1984) provide explanations of the gender of loan words in German excluding the psycholinguistic factor. Many of these explanations fall into one of two areas: morphology (including morphemes with specified gender) or semantics (including assignment of gender according to semantic field, animacy, or lexical-conceptual equivalence). Often a combination of these is offered. A further explanation is the status of masculine as the default gender. Such accounts often refer to languageinternal gender assignment processes. However, there is still no research on the principles of choosing the gender of nouns in German by Ukrainian-speaking students.

In our research we hypothesize that Ukrainian-speaking students are guided primarily by suffixes or endings of German nouns in choosing the correct gender. The mentioned above gender principles show that Ukrainian and German belong to the languages that assign nouns to gender on the one hand through formal and on the other hand through semantic criteria. However, the role of the individual assignment rules, their productivity, and their types differ significantly in both languages. In German, for example, a hierarchy of gender assignment rules is 
assumed: the assignment of gender using real word-formation suffixes dominates semantic and phonological principles. Semantic assignments are, in turn, stronger than the other phonological assignment tendencies. Such a hierarchy of gender allocation rules is observed: (1) morphological, (2) semantic, (3) phonetic. In Ukrainian language Filatova (2007, p. 141) offers the following hierarchy: (1) morphological, (2) phonetic, and (3) semantic rules. Therefore, we hypothesize that Ukrainian students when choosing gender to inanimate nouns in German are primarily based on the formal criteria and give priority to the morphological indicators over the phonetic and semantic regularities. The last ones have the lowest gender predictive power for inanimate nouns in Ukrainian, so it can be assumed that they are also dominated by morphological regularities when acquiring gender in a foreign language, where semantic or phonetic regularities are decisive.

\section{Material and Methods}

The material for the study was based on 60 nouns written out from the textbook Login 1: Deutsch für Germanistikstudenten (2009). These nouns are divided into two groups: 30 phonetic equivalents such as die Idee (engl. idea), das Problem (engl. problem), der Kaffee (engl. coffee) and 30 phonetically different nouns, such as: der Tee (engl. tea), die Frist (engl. deadline), das Gebäude (engl. building) and more. Each group contains 10 nouns of masculine, feminine and neuter gender, among which is the same number of root, derivative and complex nouns. All nouns are selected to meet certain semantic, morphological and phonetic rules of gender. Twelve nouns ( 6 equivalents and 6 phonetically different pairs of words) were selected separately for the training exercises.

To identify what criteria students use in determining the gender of German nouns, we conducted two psycholinguistic experiments with a month interval (February \& March, 2020). Each experiment included 30 Ukrainian first-yearstudents of the German Department (Chernivtsi University) with A2-B1 German level. Students were tested separately one by one. They were given the task of determining whether the noun gender specified in DMDX program (http://www.u.arizona.edu/ kforster/dmdx/download.htm) was correct. Thus, in half of the given examples the article did not correspond to the grammatical gender of a noun.

In the beginning, all students received instructions orally, which emphasized the importance of a quick response to a noun and, if possible, giving correct answers. The experiment itself consisted of two stages: in the first stage, students were trained to work with the program and determine the gender of nouns on the example of 12 nouns. Presentation of nouns and counting of reaction time took place automatically with the help of DMDX program. Nouns with articles had a sufficient size on the screen (each letter $-7 \times 8 \mathrm{~mm}$ ), students sat at a distance of $50 \mathrm{~cm}$ from the screen. The obtained results were not taken into account if the answer followed 4500 milliseconds after the presentation of a noun. The experiment lasted about 25 minutes. The time and correctness of the answers were summarized in the tables. 


\section{Results and Discussion}

\subsection{Experiment 1 with phonetic equivalents}

A total of 900 measurements were made, but 13 of them (4.3\%) were invalid due to non-compliance with the time allotted for response. As a result, 887 answers were received, 442 of which were the answers for nouns with the correct article and 445 answers for nouns with incorrect articles. Correct answers of students were recorded in 654 cases $(73.7 \%)$, mistakes - in 232 cases (Table 1).

Table 1

The results of experiment 1 (in ascending number of mistakes)

\begin{tabular}{|c|c|c|c|c|c|c|c|}
\hline \multirow[b]{2}{*}{$\begin{array}{l}\text { Word- } \\
\text { stimulus }\end{array}$} & \multicolumn{3}{|c|}{ Gender } & \multicolumn{3}{|c|}{ Coincidence } & \multirow[b]{2}{*}{$\begin{array}{c}\text { Number of } \\
\text { mistakes }\end{array}$} \\
\hline & 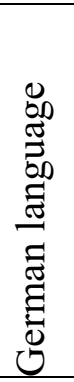 & 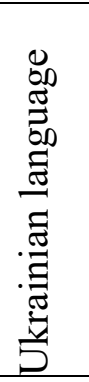 & 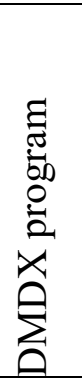 & 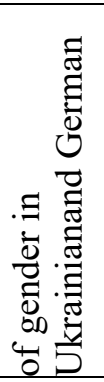 & 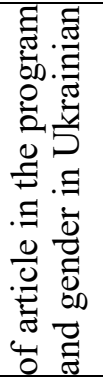 & 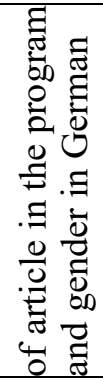 & \\
\hline Bibliothek & $\mathrm{f}$ & $\mathrm{f}$ & $\mathrm{f}$ & + & + & + & 0 \\
\hline Idee & $\mathrm{f}$ & $\mathrm{f}$ & $\mathrm{f}$ & + & + & + & 0 \\
\hline Situation & $\mathrm{f}$ & $\mathrm{f}$ & $\mathrm{f}$ & + & + & + & 0 \\
\hline Kritik & $\mathrm{f}$ & $\mathrm{f}$ & $\mathrm{f}$ & + & + & + & 1 \\
\hline Kurs & $\mathrm{m}$ & $\mathrm{m}$ & $\mathrm{n}$ & + & + & + & 1 \\
\hline Maschine & $\mathrm{f}$ & $\mathrm{f}$ & $\mathrm{n}$ & + & - & - & 1 \\
\hline Methode & $\mathrm{f}$ & $\mathrm{m}$ & $\mathrm{f}$ & - & - & + & 1 \\
\hline Kultur & $\mathrm{f}$ & $\mathrm{f}$ & $\mathrm{f}$ & + & + & + & 2 \\
\hline Computer & $\mathrm{m}$ & $\mathrm{m}$ & $\mathrm{m}$ & + & + & + & 2 \\
\hline Rhythmus & $\mathrm{m}$ & $\mathrm{m}$ & $\mathrm{n}$ & + & - & - & 2 \\
\hline Kontakt & $\mathrm{m}$ & $\mathrm{m}$ & $\mathrm{m}$ & + & + & + & 3 \\
\hline Plan & $\mathrm{m}$ & $\mathrm{m}$ & $\mathrm{n}$ & + & - & - & 3 \\
\hline Temperatur & $\mathrm{f}$ & $\mathrm{f}$ & $\mathrm{f}$ & + & + & + & 5 \\
\hline Kalender & $\mathrm{m}$ & $\mathrm{m}$ & $\mathrm{n}$ & + & - & - & 5 \\
\hline Problem & $\mathrm{n}$ & $\mathrm{f}$ & $\mathrm{f}$ & - & + & - & 5 \\
\hline Rahmen & $\mathrm{m}$ & $\mathrm{f}$ & $\mathrm{m}$ & - & - & + & 5 \\
\hline Kaffee & $\mathrm{m}$ & $\mathrm{f}$ & $\mathrm{f}$ & - & + & - & 6 \\
\hline Institut & $\mathrm{n}$ & $\mathrm{m}$ & $\mathrm{n}$ & - & - & + & 7 \\
\hline Referat & $\mathrm{n}$ & $\mathrm{m}$ & $\mathrm{n}$ & - & - & + & 9 \\
\hline Nummer & $\mathrm{f}$ & $\mathrm{m}$ & $\mathrm{m}$ & - & + & - & 10 \\
\hline Chat & $\mathrm{m}$ & $\mathrm{m}$ & $\mathrm{n}$ & + & - & - & 10 \\
\hline Plakat & $\mathrm{n}$ & $\mathrm{m}$ & $\mathrm{n}$ & - & - & + & 13 \\
\hline Instrument & $\mathrm{n}$ & $\mathrm{m}$ & $\mathrm{m}$ & - & + & - & 13 \\
\hline Tennis & $\mathrm{n}$ & $\mathrm{m}$ & $\mathrm{m}$ & - & + & - & 14 \\
\hline Dach & $\mathrm{n}$ & $\mathrm{m}$ & $\mathrm{m}$ & - & + & - & 15 \\
\hline Prozess & $\mathrm{m}$ & $\mathrm{m}$ & $\mathrm{n}$ & + & - & - & 18 \\
\hline Talent & $\mathrm{n}$ & $\mathrm{m}$ & $\mathrm{m}$ & - & + & - & 18 \\
\hline Horoskop & $\mathrm{n}$ & $\mathrm{m}$ & $\mathrm{m}$ & - & + & - & 20 \\
\hline Protokoll & $\mathrm{n}$ & $\mathrm{m}$ & $\mathrm{m}$ & - & + & - & 21 \\
\hline Region & f & $\mathrm{m}$ & $\mathrm{m}$ & - & + & - & 22 \\
\hline Total & & & & & & & 232 \\
\hline
\end{tabular}


The analysis of mistakes in determining the gender allows dividing them into 4 groups - mistakes due to: 1) interlingual interference - 10 nouns, 117 mistakes; 2) intralingual interference -2 nouns, 20 mistakes; 3 ) interlingual or intralingual interference -12 nouns, 80 mistakes; 4) other mistakes, the cause of which is difficult to identify unambiguously -6 nouns, 15 mistakes.

Interlingual interference happens when incorrectly determined gender of nouns coincides with the gender of the Ukrainian equivalent. There were 8 monosyllabic nouns with different gender in German and Ukrainian in the experiment - die Methode, das Problem, das Institut, das Tennis, das Dach, das Horoskop, das Protokoll, die Region, to which the students gave a total of 105 incorrect answers. Most mistakes are found in nouns without explicit morphological indication, such as: das Tennis (14 mistakes), das Dach (15), das Horoskop (20), das Protokoll (21), die Region (22). In this case, students are forced to either use their knowledge (if they have memorized the noun together with the article), or rely on the gender of the Ukrainian equivalent. Interlingual interference is also observed in cases of determining the gender of English borrowings such as *das Computer and *das Chat. Both words belong to the masculine gender in the Ukrainian language, and the neuter gender is assigned to them based on the English language.

Some mistakes in determining the gender are due to the phenomenon of formal and semantic rules overgeneralization, i.e. intralingual interference established for two nouns (a total of 20 mistakes). The students assigned the wrong gender to nouns due to their suffixes and endings. Thus, Latin borrowings in -us belong, as a rule, to the masculine gender, but some nouns (das Genus, das Plus, das Minus, der/das Rebus) have the neuter gender. The noun der Rhythmus belongs to the masculine gender in Ukrainian and German, but is twice marked as a neuter gender noun, apparently based on -us ending. The same is applied to the noun der Prozess, which, in spite of the masculine gender, is 16 times referred to as the neuter gender nouns in both languages (with reference to das Business), and twice to the feminine nouns (cf. die Fitness).

The influence of both interlingual and intralingual interference is observed in seven nouns - die Nummer, der Kaffee, das Talent, das Instrument, das Plakat, das Referat, der Rahmen, as here both the influence of the gender of the Ukrainian equivalent and the overgeneralization of morphological rules is found. Thus, the erroneous masculine gender in the noun die Nummer is due either to the influence of the gender of the Ukrainian equivalent, or to the overgeneralization of the typical masculine ending -er. The suffix -ee in the word Kaffee corresponds to the morphological features of the neuter gender in the words das Gelee, das Resümee, rarely feminine - in the words die Armee, die Tournee, die Livree etc. The erroneous gender *die Kaffee can be explained by analogy with die Armee, die Tournee, as well as the influence of the native language in which the noun ukr. $к а в а$ is feminine.

Many mistakes are especially caused by Latin borrowings with suffixes -at, -ent, -en: das Plakat (13 mistakes), das Instrument (13), das Talent (18), der Rahmen (5). The suffix - at vaguely indicates the gender: nouns of the neuter gender to denote a place or institution are formed with it (Konsulat, Sekretariat, Notariat), 
also those denoting process (Diktat, Telefonat, Testat), result (Konzentrat, Filtrat) and collective nouns (Proletariat, Prekariat), and much more frequent denotations of males (Stipendiat, Kandidat, Soldat), which cause erroneous determining of the gender in the nouns *der Plakat, *der Referat. The cause of mistakes in determining the gender is incorrect analogy in the nouns *der Talent, *der Instrument (cf. der Student, der Dozent, der Konkurrent), *der Klingel (cf. der Löffel, der Deckel), etc. The rest of the mistakes are due to incorrect (arbitrarily assigned) gender in the program DMDX. Thus, the masculine gender nouns der Kurs and der Plan were interpreted by most students as nouns of the neuter gender according to the program data, despite clearly expressed phonetic criteria. Nouns die Kritik, die Kultur, der Kontakt and die Temperatur students erroneously assigned to the neuter gender because they considered them abstract nouns. In general, the obtained results indicate that the gender of the noun of the native language significantly affects the determining of the gender of the German phonetic equivalent (197 mistakes, i.e. $85 \%$ of mistakes caused by interlingual interference).

Our results correlate with the results of checking the exercise books of students who participated in the experiment: the most numerous are mistakes in determining the gender of nouns in German that do not have a clear morphological link, such as: Jeder braucht *seinen Dach über dem Kopf. Diesem Bild liegt *der religiöse Sujet zugrunde. Man muss *eine aktuelle Passfoto zeigen. In der Sitzung hat man *einen genauen Protokoll geführt. In terms of the frequency of mistakes nouns with a clear morphological indication are in the second place, but the gender of the phonetically similar noun in the Ukrainian language is attributed to the German noun: *Der Universität hat drei Fakultäten. Die besten Chancen auf dem Arbeitsmarkt haben die Absolventen *der Gymnasium. Die Schüler wollten gestern *ihren Referat halten, aber der Unterricht fiel aus.

Mistakes in nouns, the gender of which coincides in the Ukrainian and German languages, are also interesting. Obviously, morphological indicators in the German language are the causes of the mistakes, such as: Wir sind in *die Café gegangen (cf. die Garderobe, die Anprobe, etc.).

Proper nouns of foreign origin with their gender in Ukrainian are usually used when translating into German, such as: *Der schöne Berlin ist 800 Jahre alt. Die Geschichte *der modernen Europa beginnt im Mittelalter. Berlin liegt an der Mündung der Spree in *den Havel.

It is especially difficult to eradicate mistakes caused by the interfering influence of the native language on German, which are additionally supported by morphological factors of the German language, such as: ${ }^{*}$ Der Wintersemester beginnt im Oktober (based on the typical masculine gender ending -er). *Der künstlerische Talent des Meisters war groß (based on the typical ending of masculine gender borrowings -ent: Student, Dirigent, Konkurrent, etc.). At the same time, students sometimes adapt German endings to the corresponding Ukrainian ones: Die Hypnose ist *der Lieblingsmethod-o vieler Ärzte. Das Bild umgibt *eine schöne Rahme. *Der Visit-o endete spät. All this additionally testifies in favour of the native language interference when learning a foreign language. 


\subsection{Experiment 2 with semantic equivalents}

There were 30 phonetically different pairs of semantic equivalents selected for experiment 2. 900 measurements were performed, during which the time limit was not exceeded. As a result, students gave 450 answers for nouns with the correct and incorrect article. The number of correct answers is 711 cases $(78.8 \%)$. During the experiment, 189 mistakes were recorded, which is 43 mistakes less than in the experiment with interlingual phonetic equivalents (Table 2).

Table 2.

The result of experiment 2 (in ascending number of mistakes)

\begin{tabular}{|c|c|c|c|c|c|c|c|}
\hline \multirow[b]{2}{*}{ Word-stimulus } & \multicolumn{3}{|c|}{ Gender } & \multicolumn{3}{|c|}{ Coincidence } & \multirow[b]{2}{*}{$\begin{array}{c}\text { Number of } \\
\text { mistakes }\end{array}$} \\
\hline & 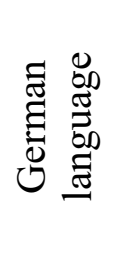 & 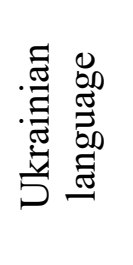 & 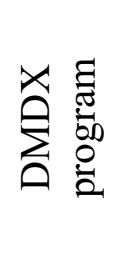 & 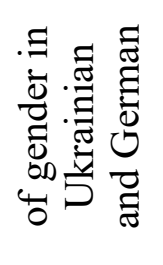 & 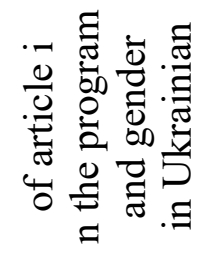 & 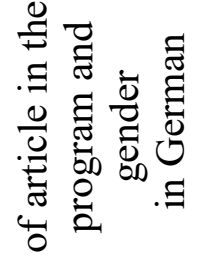 & \\
\hline Bier & $\mathrm{n}$ & $\mathrm{n}$ & $\mathrm{n}$ & + & + & + & 0 \\
\hline Mannschaft & $\mathrm{f}$ & $\mathrm{f}$ & $\mathrm{f}$ & + & + & + & 0 \\
\hline Mensa & $f$ & $\mathrm{f}$ & $\mathrm{f}$ & + & + & + & 0 \\
\hline Mitternacht & $\mathrm{f}$ & $\mathrm{f}$ & $\mathrm{f}$ & + & + & + & 0 \\
\hline Tee & $\mathrm{m}$ & $\mathrm{m}$ & $\mathrm{m}$ & + & + & + & 0 \\
\hline Blick & $\mathrm{m}$ & $\mathrm{m}$ & $\mathrm{m}$ & + & + & + & 2 \\
\hline Zeuge & $\mathrm{m}$ & $\mathrm{m}$ & $\mathrm{m}$ & + & + & + & 2 \\
\hline Wecker & $\mathrm{m}$ & $\mathrm{m}$ & $\mathrm{m}$ & + & + & + & 3 \\
\hline Gebäude & $\mathrm{n}$ & $\mathrm{f}$ & $\mathrm{f}$ & - & + & - & 4 \\
\hline Traum & $\mathrm{m}$ & $\mathrm{m}$ & $\mathrm{m}$ & + & + & + & 4 \\
\hline Fisch & $\mathrm{m}$ & $\mathrm{f}$ & $\mathrm{m}$ & - & - & + & 4 \\
\hline Urlaub & $\mathrm{m}$ & $\mathrm{f}$ & $\mathrm{n}$ & - & - & - & 4 \\
\hline Gefühl & $\mathrm{n}$ & $\mathrm{n}$ & $\mathrm{f}$ & + & - & - & 5 \\
\hline Name & $\mathrm{m}$ & $\mathrm{n}$ & $\mathrm{f}$ & - & - & - & 5 \\
\hline Glück & $\mathrm{n}$ & $\mathrm{n}$ & $\mathrm{m}$ & + & - & - & 5 \\
\hline Ort & $\mathrm{m}$ & $\mathrm{f}$ & $\mathrm{m}$ & - & - & + & 6 \\
\hline Geschenk & $\mathrm{n}$ & $\mathrm{m}$ & $\mathrm{m}$ & - & + & - & 6 \\
\hline Unternehmen & $\mathrm{n}$ & $\mathrm{n}$ & $\mathrm{m}$ & + & - & - & 6 \\
\hline Regel & $\mathrm{f}$ & $\mathrm{n}$ & $\mathrm{f}$ & - & - & + & 8 \\
\hline Käse & $\mathrm{m}$ & $\mathrm{m}$ & $\mathrm{f}$ & + & - & - & 9 \\
\hline Ende & $\mathrm{n}$ & $\mathrm{m}$ & $\mathrm{f}$ & - & - & - & 9 \\
\hline Pflicht & $\mathrm{f}$ & $\mathrm{m}$ & $f$ & - & + & - & 9 \\
\hline Heirat & $\mathrm{f}$ & $\mathrm{n}$ & $\mathrm{m}$ & - & - & - & 9 \\
\hline Ticket & $\mathrm{n}$ & $\mathrm{m}$ & $\mathrm{n}$ & - & - & + & 10 \\
\hline Mitglied & $\mathrm{n}$ & $\mathrm{m}$ & $\mathrm{n}$ & - & - & + & 10 \\
\hline Beschwerde & $\mathrm{f}$ & $\mathrm{f}$ & $\mathrm{n}$ & + & - & - & 12 \\
\hline Vorwahl & $\mathrm{f}$ & $\mathrm{m}$ & $\mathrm{m}$ & - & + & - & 13 \\
\hline Herkunft & $\mathrm{f}$ & $\mathrm{n}$ & $\mathrm{n}$ & - & + & - & 13 \\
\hline Frist & $\mathrm{f}$ & $\mathrm{m}$ & $\mathrm{m}$ & - & + & - & 15 \\
\hline Millieu & $\mathrm{n}$ & $\mathrm{n}$ & $\mathrm{m}$ & + & - & - & 16 \\
\hline Total & & & & & & & 189 \\
\hline
\end{tabular}


Similarly to mistakes in determining the gender of phonetic equivalents, we have divided the mistakes recorded in Experiment 2 into 4 groups due to: 1) interlingual interference - 10 nouns, 89 mistakes; 2) intralingual interference 5 nouns, 33 mistakes; 3) interlingual or intralingual interference -2 nouns, 12 mistakes; 4) other mistakes, the cause of which is difficult to identify unambiguously - 12 nouns, 55 mistakes.

The results show that $47 \%$ of all mistakes are due to interlingual interference (see nouns der Fisch, das Geschenk, die Pflicht), for which the students chose the neuter gender. Intralingual interference is observed in the nouns der Zeuge, der Name, der Käse, das Ende, which students attributed to the feminine gender, apparently based on the typical suffix -e. The noun die Regel is erroneously classified as masculine based on the typical suffix -el. The influence of both types of interference is recorded in the nouns das Gebäude and das Ticket, which are assigned the wrong gender either based on the gender of Ukrainian equivalents, or given the morphological structure of nouns. However, the largest number of mistakes was found in nouns without explicit morphological indicators, such as: die Pflicht (9 mistakes), die Heirat (9), die Vorwahl (13), die Herkunft (15). In these cases, students had to rely on their knowledge or decide in favor of a certain gender intuitively. Phonetic inconsistency of semantic equivalents does not allow using the gender of Ukrainian nouns as widely in determining the gender in German as in Experiment 1 . In some cases it is difficult to unambiguously identify the factor that influenced the choice of gender, especially in nouns with the same gender in both languages and explicit morphological marking, such as der Wecker, die Beschwerde, das Milieu. For example, the noun die Beschwerde is erroneously ascribed the neuter gender because it is abstract. The noun das Milieu was interpreted by students as a French borrowing and, based on the two-member French category of the gender, was erroneously defined in 16 cases not as a noun of the neuter gender.

Additionally, students received questionnaires after the experiment, in which they had to indicate the reasons for their choice in favor of a certain gender of a noun in German. This allowed us to determine the strategies that guide students in determining the gender of a noun (Table 3 )

Table 3.

Strategies for determining the gender of nouns

\begin{tabular}{lccc}
\hline $\begin{array}{l}\text { Strategies for determining } \\
\text { gender of nouns }\end{array}$ & $\begin{array}{c}\text { Phonetic } \\
\text { equivalents }\end{array}$ & $\begin{array}{c}\text { Semantic } \\
\text { equivalents }\end{array}$ & Total \\
\hline $\begin{array}{l}\text { learned by heart } \\
\text { emotional decision }\end{array}$ & 180 & 311 & 491 \\
phonetic rules (the & 191 & 155 & 346 \\
$\quad \begin{array}{l}\text { beginning of the word) } \\
\text { morphological rules (the }\end{array}$ & 193 & 124 & 27 \\
$\begin{array}{l}\text { end of the word) } \\
\text { meaning of the noun }\end{array}$ & 29 & 79 & 317 \\
$\begin{array}{l}\text { length of the noun } \\
\text { gender of the noun in }\end{array}$ & 13 & 39 & 108 \\
Ukrainian & 175 & 39 & 214
\end{tabular}


gender of the noun in the

75

48

123

experiment

own answer

25

84

109

Total

887

900

1787

Analysis of the questionnaires showed that in most cases (491) students memorized the words with the specified article. In 346 cases, students admitted that they acted based on their own feelings, which indicates uncertainty or ignorance of the rules for determining the gender of nouns. It should be noted that students assigned gender to nouns, as a rule, according to the Ukrainian language. This fact is also confirmed by many mistakes in the gender of phonetically similar nouns. In 317 cases, students focused on the endings of nouns in German, i.e. relied on the morphological indicators. Students used the semantic rules of determining the gender only in 108 cases, most often to identify the gender of abstract nouns and nouns denoting drinks. In this case, borrowings from the English language were assigned, as a rule, the neuter gender. The length of the noun and phonetic rules relating to the beginning of the word, play a secondary role in determining the gender of nouns. Students guess that short nouns are most often of masculine gender, but rarely use this rule. The attention is paid to the beginning of the word only when it comes to the prefix Ge-, for example: das Geschenk, das Gefühl. In 123 cases, students chose the gender proposed in the experiment because it seemed plausible or convincing.

Figure 1 shows a strong focus on gender in the Ukrainian language while determining the gender of phonetic equivalents and the significant role of learning words together with the article in semantic equivalents.

Figure 1.

Strategies for determining the gender of nouns in German

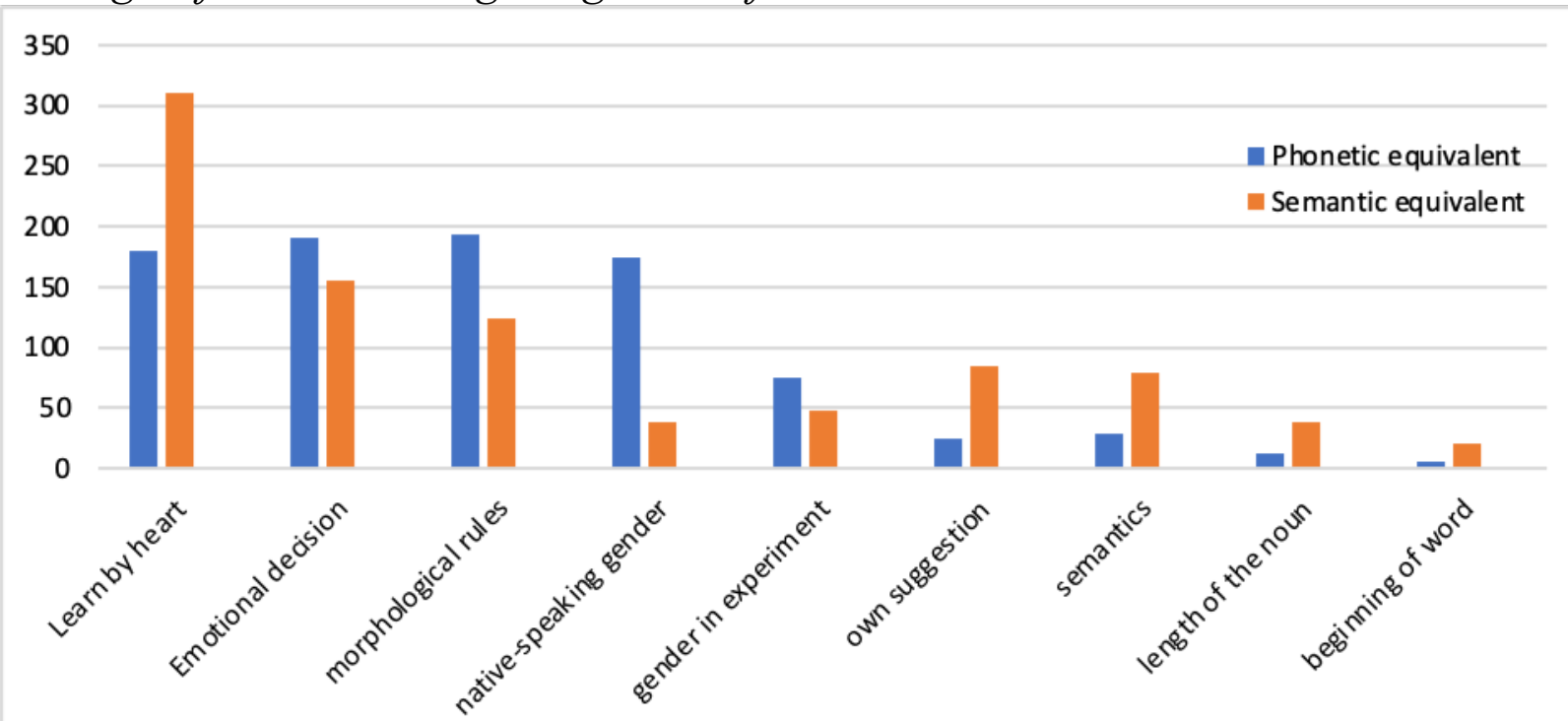


The question on "the assignment of gender to a particular noun by default when it is impossible to rely on any other gender determination strategies" (di Meola 2007, p. 87), which is considered in a number of works, remains unsolved. Thus, it was noted in the hypothesis in the work of the Italian researcher di Meola that such default gender is neuter, which is assigned in the mental lexicon to foreign words (Handy) or words that are rarely used with the article (Tennis). Another approach is taken by Steinmetz (1986, p. 214), which highlights the following hierarchy in the assignment of the gender: masculine $>$ feminine $>$ neuter. If it is difficult to find rules for determining the gender, then the noun is automatically assigned to the masculine gender. Additional research is needed to determine whether Ukrainian-speaking students follow this principle.

\section{Conclusions}

Previous studies on noun gender in German have focused on the printed word, highlighting the importance of semantics over morpho-phonological analogy in gender assignment to foreign nouns (Onysko et al. 2013). The results of two experiments indicate that the Ukrainian students of the Chernivtsi University (German department) are guided primarily by suffixes or endings of German nouns in choosing the correct gender. Phonetic or semantic rules for determining gender play a secondary role. Interference phenomena are observed in determining the gender: the gender of a noun in the native language prevents the correct choice of gender in German, which is twice as often recorded in phonetic equivalents. Therefore, the results of the present study demonstrate the importance of morphological factor above all others in the gender assignment to German nouns.

Overall, based on the critical appraisal of previous research, and based on the findings of the present research, it may be concluded that an exhaustive theory regarding the assignment of gender to German nouns is yet to be formulated. However, this paper has attempted to show that gender choosing for German nouns adhere to the overall patterns of the native Ukrainian gender paradigm.

The prospects for further study lie in the development of a system of exercises to determine the gender of nouns in German, taking into account the results, which will contribute to successful work with the language material, systematize and generalize existing knowledge and skills to use phonetic, morphological and semantic indicators of nouns in German, form skills of counteracting the impact of interlingual interference.

\section{References}

Bewer, F. (2003). Der Erwerb des Artikels als Genus-Anzeiger im deutschen Erstspracherwerb. Studies on the development of grammar in German, Russian and Bulgarian. (pp. 87-140). Berlin: ZAS.

Bordag, D. (2006). Psycholinguistische Aspekte der Interferenzforschungen in der Flexionsmorphologie des Tschechischen als Fremdsprache. Hildesheim: Georg Olms Verlag.

Di Meola, C. (2007). Neutrale Genuszuweisung im Deutschen. Perspektiven Zwei: Akten der 2. Tagung Deutsche Sprachwissenschaft in Italien (Roma, 9.-11.2.2006). Hrsg. von Claudio 
di Meola, Livio Gaesta \& Antonie Hornung. Rom: Istituto Italiano di Studi Germanici. (8799).

Doleschal, U. (2004). Genus als grammatische und textlinguistische Kategorie. Eine kognitivfunktionalistische Untersuchung des Russischen. München: Lincom Europa.

Filatova, N. (2007). Ukrainisch im Kontakt mit anderen europäischen Sprachen. Englische, deutsche, russische Entlehnungen im Bereich der Politik. Erlangen-Nürnberg: Universitätsverlag.

Helbig, G. \& Buscha, J. (2001). Deutsche Grammatik: Ein Handbuch für den Ausländerunterricht. Berlin: Langenscheidt.

Hunt, J. W. (2018). The gender of anglicisms in spoken German, Word, 64(2), 103-125. https://doi.org/10.1080/00437956.2018.1463002

Kiyko, S. (2017). Faux amis als Interferenzquelle im DaF-Unterricht. Festschrift für Ulrich Steinmüller zum 75. Geburtstag. Hartung, Nicole; Zimmermann, Kerstin (Hrsg.). (pp. 151172). Berlin: Universitätsverlag der TU.

Köpcke, K.-M. (1982). Untersuchungen zum Genussystem der deutschen Gegenwartssprache. Tübingen: Niemeyer.

Login 1: Deutsch für Germanistikstudenten (2009). O. Sidorow (Ed.). Winnyzja: Nova Knyha.

Menzel, B. (2004). Genuszuweisung im DaF-Erwerb. Psycholinguistische Prozesse und didaktische Implikationen. Berlin: Weißensee.

Onysko, A., Callies, M., \& Ogiermann, E. (2013). Gender variation of anglicismsin German: The influence of cognitive factors and regional varieties. Poznan Studies in Contemporary Linguistics, 49(1). 103-36.

Schwichtenberg, B. \& Schiller, N.O. (2004). Semantic gender assignment regularities in German. Brain and Language, 90(1-3). 326-37. https://doi.org/10.1016/S0093-934X(03)00445-0

Sperber, H. (1989). Mnemotechniken im Fremdsprachenerwerb mit Schwerpunkt „Deutsch als Fremdsprache “. München: Iudicium.

Spitz, E. (1965). Beitrag zur Genusbestimmung der deutschen Substantive. Deutsch als Fremdsprache, 2, 35-43.

Steinmetz, D. (1986). Two principles and some rules for gender in German inanimate nouns. Word, 37(3), 189-217. https://doi.org/10.1080/00437956.1986.11435777

Steinmetz, D. (2006). Gender shifts in Germanic and Slavic: Semantic motivation for neuter? Lingua, 116, 14-40.

Zubin, D.A. \& Köpcke, K.-M. (1984). Affect classification in the German gendersystem. Lingua, 63, 41-96. https://doi.org/10.1016/0024-3841(84)90031-7 